تأثير غلظت نيتروزن و كلسيم محلول غذايى بر رشد، عملكرد و نوكسوختخى كاهو در كشت شناورى

\author{
عفتالسادات مرتضوى'، رحيم برزگر 'ي* و سعيد ريزى'
}

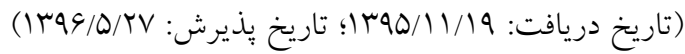

جكيده

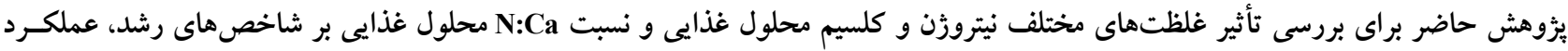

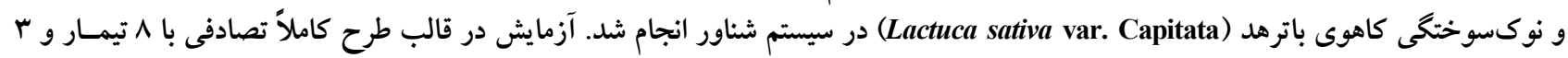

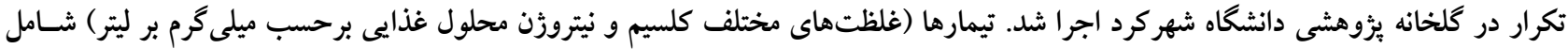

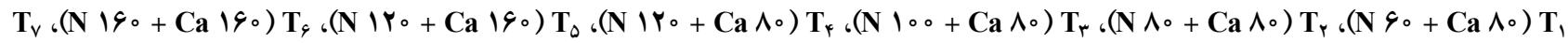

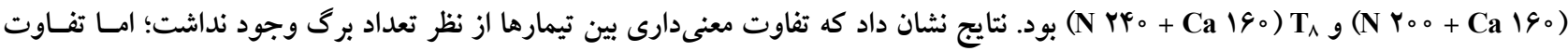

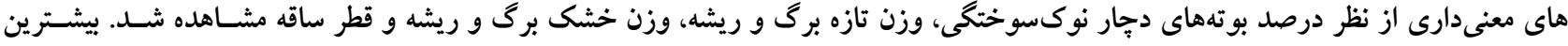

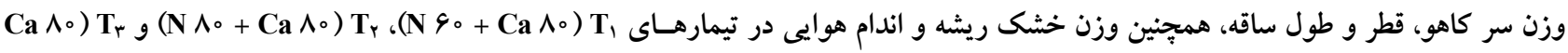

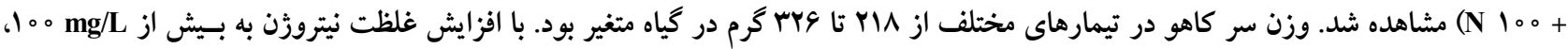

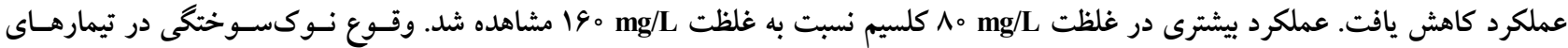

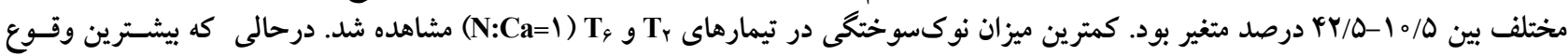

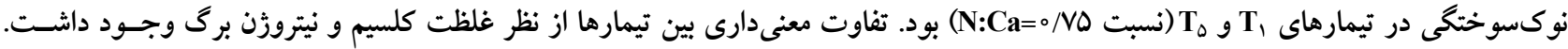

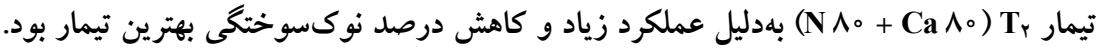

كلمات كليدى: كاهو، كثت بدون خاك، نسبت عناصر، وزن سر كاهو، نيتروزن برى

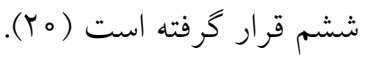

مقدمه

كشت بدون خاك يكى از راهكارهاى مهـم در بهينهسـازى

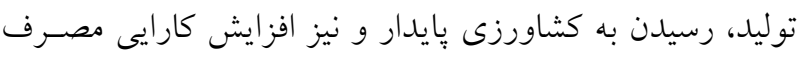

كاهو از يرمصرفترين سبزىهاى بركى است كه توليــ سـالانه

آب است (ه广). سيستم كشت شناور، مناسبترين سيستم كشت

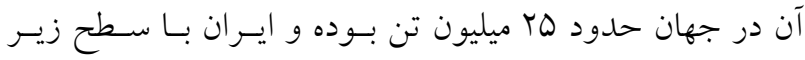

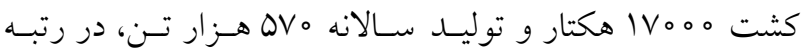

1. كروه علوم باغبانى، دانشكده كشاورزى، دانشكاه شهركرد

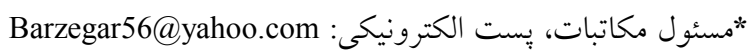


كمبود كلسيم است در اواخر دوره رشد با توسعه ناحيه نكـروزه در نوى و حاشيه برگهاى جوان و در حال رشد سريع، نمايـان مىشود و در موارد شديد ممكن است نيمى از مساحت برى را

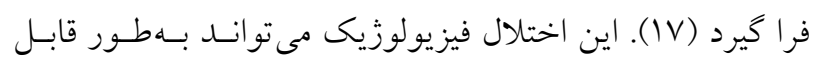
توجهى سبب كاهش عملكرد و از دست رفتن ارزش اقتصـادى شود (r). محدوده وسيعى از عواملى مانند شدت نور، فتويريود، دماى زياد، تعرق و سطوح كلسيم و نيتروزن محلـول غـذايى از

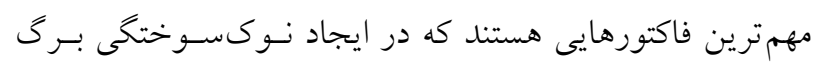
نقش دارند (V). بين شيوع نوكسوختكى و سـرعت رشـد كيـاه همبستخى مثبتى مشاهده شده است. به كونـهاى كـه بـا افـزايش سرعت رشد كياه تحت شـرايط محيطى كنتـرل شـده، احتمـال كمبود كلسيم در حاشيه بركها و خطـر شـيوع نـوكسـوختخى

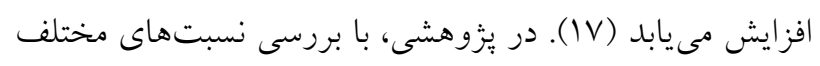

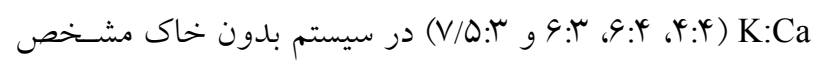
شد كه افزايش نسـبت K:Ca سـبـ افـزايش غلظـت كاهش غلظت كلسيم برى و قطر در كياه شيكوره شـد. افـزايش

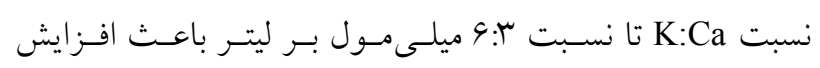

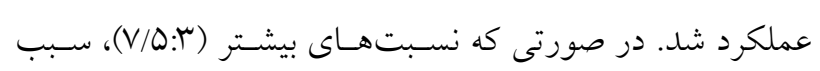

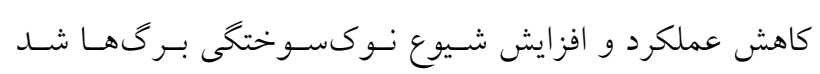
(rV) غذايى سبب كاهش جذب كلسيم در كاهو شد (ها (). از آنجـايى كه تعادل عناصر غذايى در محيط كشت از فاكتورهـاى مـؤثر در

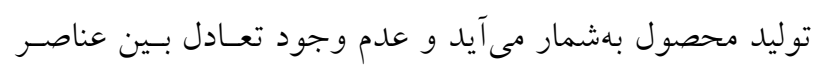

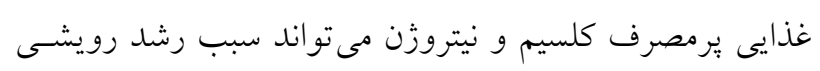

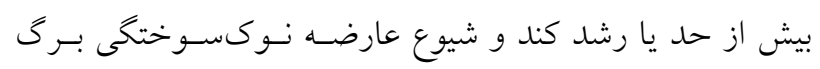
شود، لذا تعيين غلظت و نسبت بهينه اين دو عنصسر در محلـول غذايى مى تواند به توسعه كشت شناورى كاهو و به.بـود كيفيـت

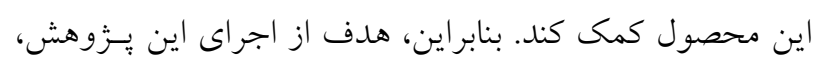
بررسى تأثير غلظتهاى هر يك از عناصر نيتـروزن و كلسـيم و

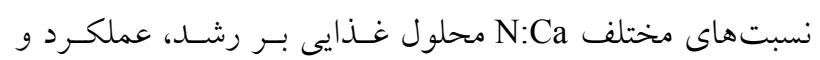

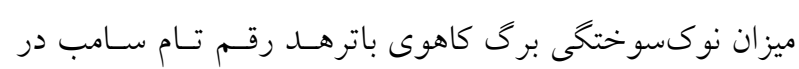
كشت شناورى در شرايط كرم بود.
بدون خاك براى سبزىهاى برگى اسـت كـه داراى دوره رشـد كوتاه بوده و برداشت آنها طى ب-9 هفته يس از جوانهائى بـى بـى انجام

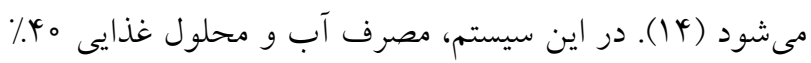
كمتر از سيستم كشت باز بوده و به محيطزيست آسيب كمتـرى

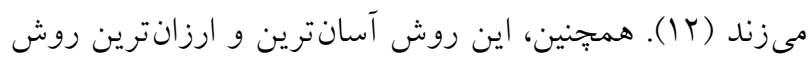
توليد سبزىهاى بركى است (Y) (Y). اين سيستم توليــ محصـول،

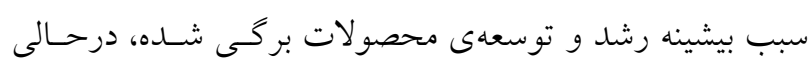

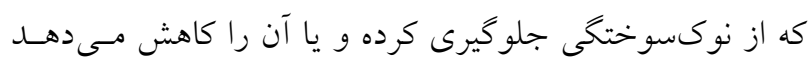

تغذيه مناسب، از عوامل كليدى در تعيين عملكرد و كيفيـت سبزىهاى بركى اسـت (V) و كتــرل صسحيح تغذيسه كياهـان، برترى اصلى كشت بدون خاك است (هั). در تغذيه صحيح، نه تنها بايد هر عنصر به اندازه كافى در دسترس گيـاه قـرار گيـرد، بلكه ايجاد تعادل و رعايت نسبت ميان عناصر غذايى از اهميـت ويزماى برخوردار است (با). در صورت عـدم تعـادل محلـول غذايى، اختلالاتى در رشد كياه ايجاد شده كه ممكن است منجر به كاهش عملكرد يا كيفيت آن شود (بم). نيتروزن يك عنصر كليدى براى عملكرد محصـول اسـت و مقدار بهينه آن سبب تسريع در تشكيل سر كاهو و تأخير در بـهـ گل رفتن، افزايش تعداد و سطح برى در كاهو مسىشـود (11). كلسيم نيز يكى از مهمترين عناصر غـذايى و جزئسى از يكتـات كلسيم، ماده سازنده ديواره سلولى است و سبب پايدارى غشاى لئى سلولى و به تأخير انداختن وييرى مسى شـود (Y). كمبـود كلسـيم

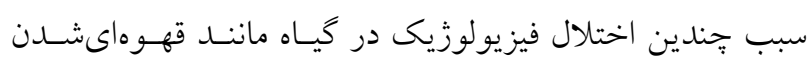
حاشيه برگها (نوكسوختخى) در كاهو، كوتاهماندن بـرگهـاى كرفس، قهوهاىشدن سر كلمبيج و بوسـيدگى انتهايى كلجـا در كوجه فرنخى مى شود (19). كمبود كلسيم نتيجه كـاهش غلظـت

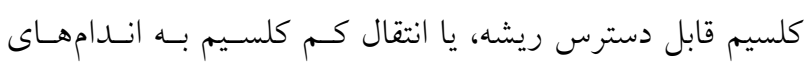

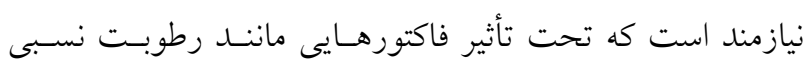
زياد، سرعت رشد، شدت تعرق و شـورى محسيط ريشــه اسـت

عارضه فيزيولوزيك نوكسوختكى برى كاهو كه مـرتبط بــا 
بلاستيك سياهرنخ يوشانيده شد. سـبس، استتخر تـا ارتفـاع سانتى متر با محلول غذايى بر شد و ورقهاى يونوليت بـهـ ابعـاد

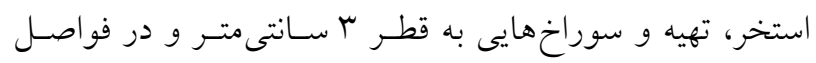

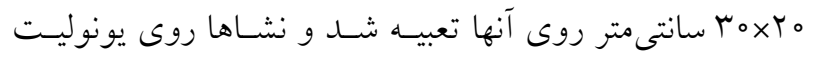

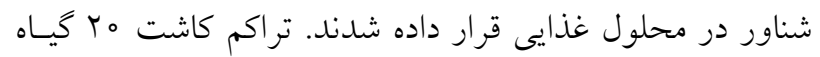

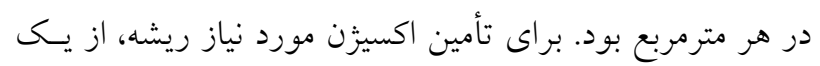
بمٍٍ هوا استفاده شد. محلول غذايى در طول دوره تنها يـكبـار

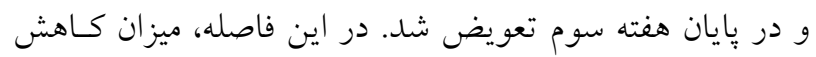

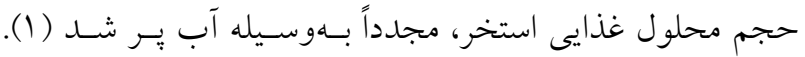

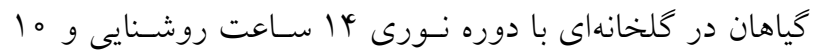
ساعت تاريكى، در دماى شب ل1 و روز TO درجه سلسيوس، و و رطوبت نسبى •ه\%٪ رشد كردند. در نهايت، بَا روز پِ از كشت نشاها، بوتهــاى كـاهو بــهـ مرحله برداشت رسيدند. در انتهاى آزمايش و پِ از اتمـام دوره

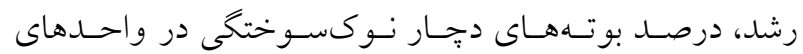

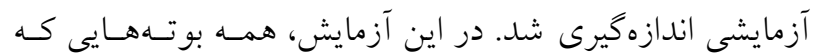

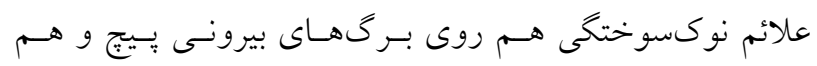

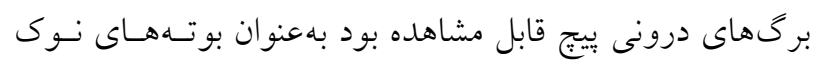

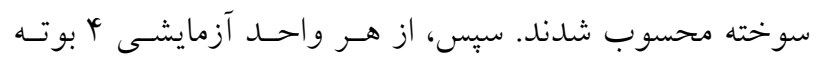

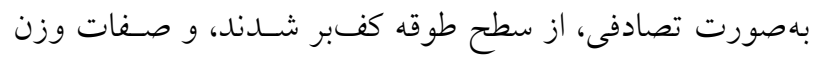

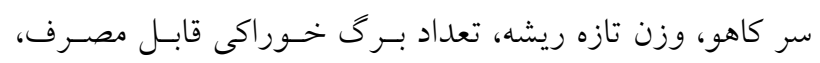

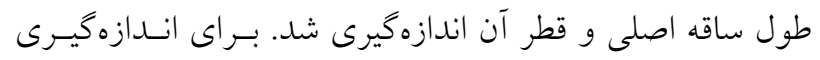

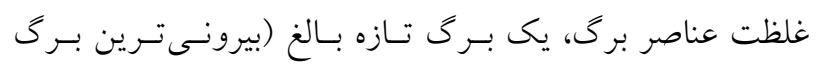

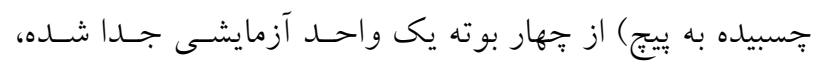

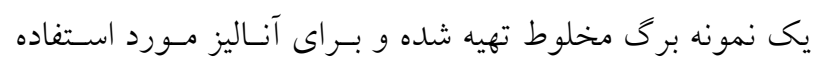

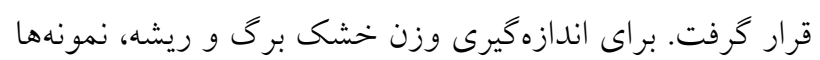

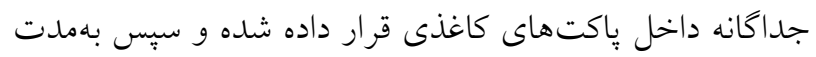
Vاعت در آون با دماى ه9 درجه سلسيوس قرار داده شدند.

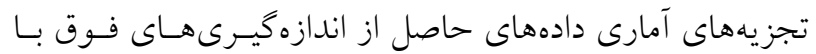

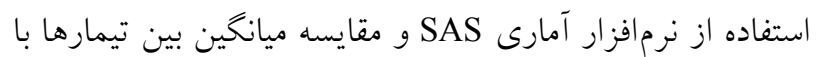

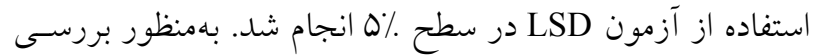
روابط بين صفات، همبستكى بين صفات تعيين شد.

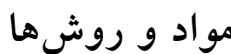

اين يزوهش در سال \& بrا در كلخانه تحقيقاتى دانشكاه شهركرد

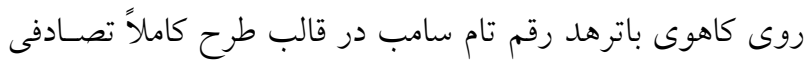

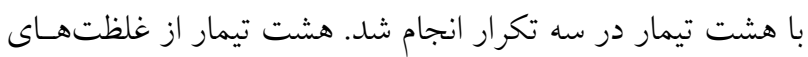

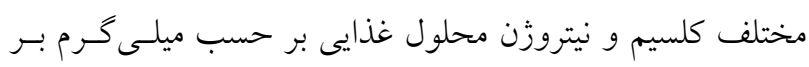

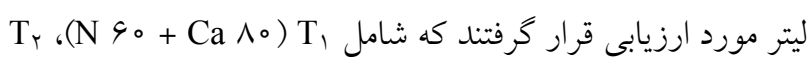
$\left.+\mathrm{Ca} \Lambda_{0}\right) \mathrm{T}_{\psi} ،\left(\mathrm{~N} 100+\mathrm{Ca} \Lambda_{0}\right) \mathrm{T}_{r}\left(\mathrm{~N} \Lambda_{0}+\mathrm{Ca} \Lambda_{0}\right)$ $\mathrm{T}_{V} ،(\mathrm{~N} 190+\mathrm{Ca} 190) \mathrm{T}_{\varphi}\left(\mathrm{N} \mid Y_{0}+\mathrm{Ca} 190\right) \mathrm{T}_{\Delta}\left(\mathrm{N} \mid \mathrm{Y}_{0}\right.$

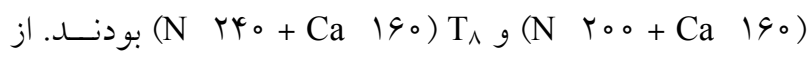

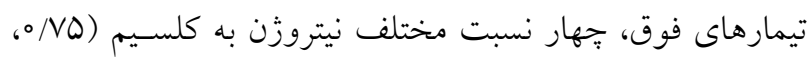

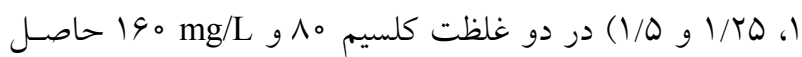

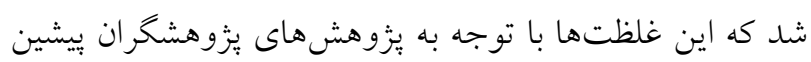

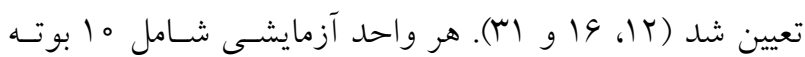

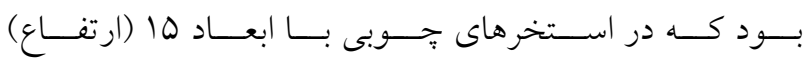

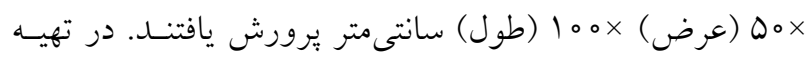

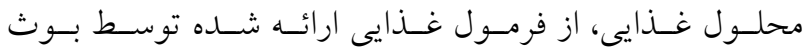
(T) استفاده شد (جــول (I). ولى غلظـت عناصـر نيتـروزن و كلسيم در آن متناسـب بـا تيمـار مـورد نظـــ تغييـر داده شـــ و نسبتهاى مختلفى از N/Ca بـهدست آمــ. EC و pH محلـول

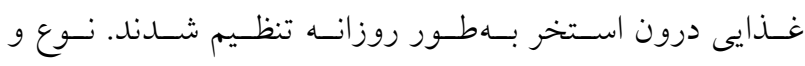

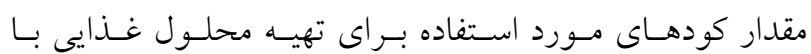

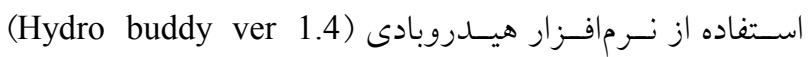
مشخص شد و كليه كودهاى مصرفى ساخت شـركت اس كيـوام

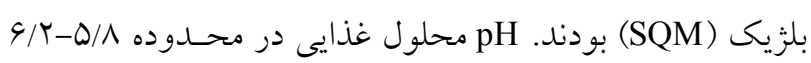
و

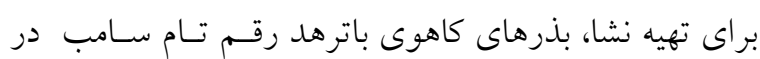

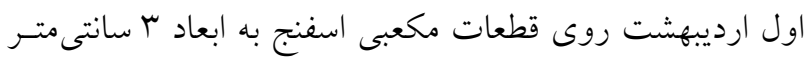

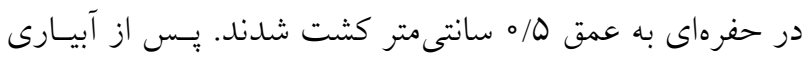

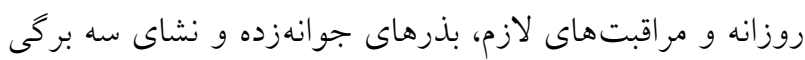

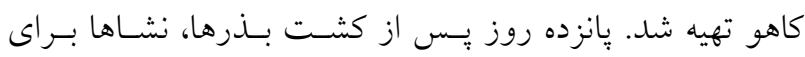

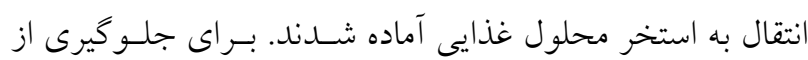

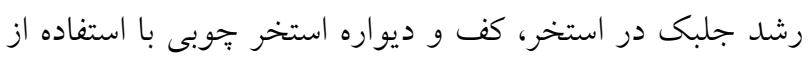


جدول ا. غلظت عناصر غذايى برمصرف و كممصرف در محلول غذايى بر حسب ميلى

\begin{tabular}{|c|c|c|c|c|c|c|c|c|c|}
\hline $\mathrm{Cu}$ & Mo & $\mathrm{Mn}$ & B & $\mathrm{Zn}$ & $\mathrm{Fe}$ & S & $\mathrm{Mg}$ & $\mathrm{P}$ & $\mathrm{K}$ \\
\hline$\circ / \circ \mu$ & $\circ / \circ \mu$ & $0 / \mid Y^{c}$ & $0 / 19$ & & 1 & ro & YY & rl & T10 \\
\hline
\end{tabular}

\begin{tabular}{|c|c|c|c|c|c|c|}
\hline وزن خشك برى & وزن تازه ريشه & وزن سر كاهو & قطر ساقه & طول ساقه & تعداد برى & \\
\hline & & & & & $\circ / \Gamma \circ q^{*}$ & طول ساقه \\
\hline & & & & $\circ / 09 V^{* *}$ & 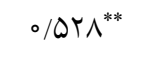 & قطر ساقه \\
\hline & & & $0 / 990^{* *}$ & $\circ /$ YYq** &.$/ 99 V^{* *}$ & وزن سر كاهو \\
\hline & & $0 / 9 \wedge 1^{* *}$ & $\circ / 4 q V^{* *}$ & $0 / l k 4$ & $\circ / 0 Y q^{* *}$ & وزن تازه ريشه \\
\hline & $\circ / 1 Q V$ & $\circ / T V \wedge^{*}$ & $\circ / \Gamma \Delta \circ * *$ & $\circ / \mu q V^{* *}$ & O/TYV & وزن خشك برى \\
\hline o/MYI $\left.\right|^{* *}$ & $\circ / \circ \vee \wedge$ & \%०Yq & $\circ / \Upsilon 90^{*}$ & $\circ / \backslash \wedge \vee$ & $-0 / 099$ & وزن خشك ريشه \\
\hline
\end{tabular}

اما تأثير معنىدارى بر تعداد برى يافت نشد.

\section{نتايج و بحث}

\section{نو كسوختخى برى}

نتـايج تجزيـه واريـانس دادههـا (جــدول س) نشـان داد كـه اتــر تيمارهاى مختلف بر نوىسوختكى برگ در سـطح احتمـال I٪

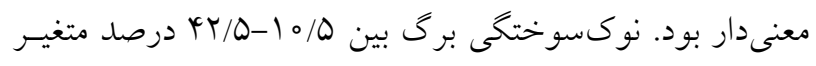

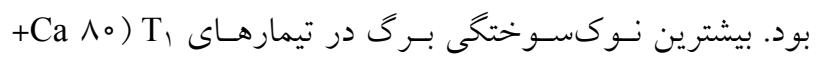

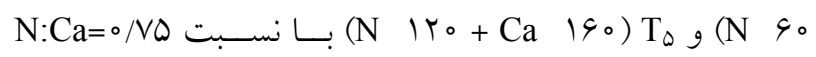

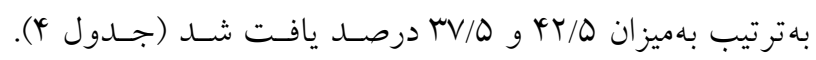

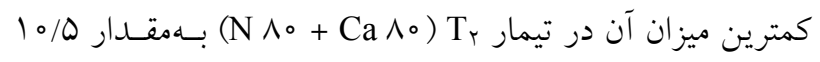

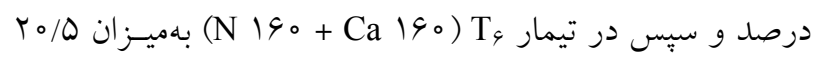
درصد مشاهده شد كه در آن نسبت N:Ca برابر ابود. نوكسوختكى برگ از دو جنبه غلظت هر يك از اين عناصر و نسبت N/Ca در محلول غذايى قابل بررسى است. زياد بــودن ميزان نوكسوختكى در نسبت N:Ca برابر VD/ه، مىتواند ناشى از كاهش سرعت جذب و انتقال يون كلسـيم بـهـعــوان كـاتيون همراه بهعلت كاهش مقدار جذب آنيون نيترات باشد (YT). ايسن موضوع بهخوبى در شكل ( (1) قابـل مشـاهده اسـت. بـا كـاهش غلظت نيتروزن محلول غذايى و كاهش جذب آن، انتقال كلسيم
تجزيه همبستكى صفات (جــدول Y) نشـان داد كـه صـفات تعـداد

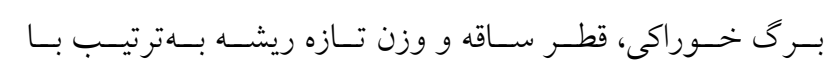

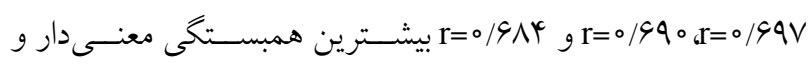
مثبت (p>0/0 ) را با صفت وزن سر كاهو داشـتند. نتـايج مشـابهى

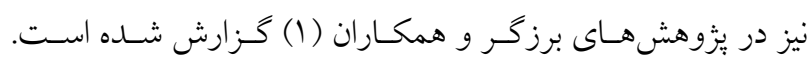
تعداد برگ، همبستخى مثبت و معنى دارى با قطر ساقه (r=o/DY و وزن تازه ريشه (r=o/Drq**) داشت. علاوه بر آن، بـين وزن تـازه ريشه با صفت تعداد برى خوراكى نيز همبستخى معنسى دار و مثبـت

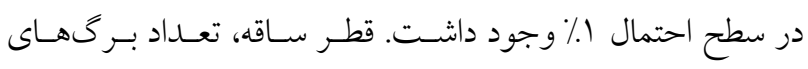

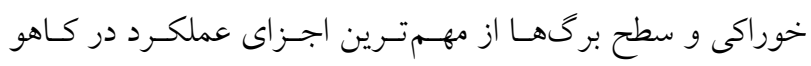

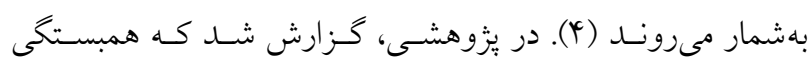
قوىاى (r=o/VV) بين قطر سـاقه و وزن سـر كـاهو در شـش رقـم كاهو وجود داشت و قطر ساقه مسىتوانـــ بـهـعنـوان معيـارى بـراى بيشبينى وزن سر كاهو مورد استفاده قرار كيرد ( (1). نتايج تجزيه واريانس دادهها (جدول س) نشـان داد كـه بـين

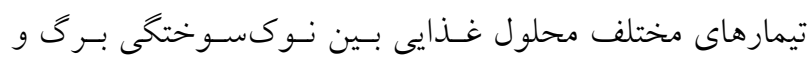
شاخصهاى رويشى مانند وزن تازه و خشك برگ، وزن تـازهو خشك ريشه، قطر و طول ساقه تفاوت معنى دارى مشاهده شـــ 
جدول س. تجزيه واريانس اثر تيمارهاى مختلف بر صفات مورد بررسى

\begin{tabular}{|c|c|c|c|c|c|c|c|c|c|}
\hline \multicolumn{8}{|c|}{ ميانخين مربعات } & \multirow{3}{*}{ آزادى } & \multirow{3}{*}{ تغنير ابع } \\
\hline قطر & & وزن خشك & وزن تازه & وزن خشك & وزن سر & & نوى & & \\
\hline ساقه & ساقه & ريشه & ريشه & برى & كاهو & برى & سوختلى & & \\
\hline $0 / 90^{* *}$ & $r \circ / \circ \wedge^{* *}$ & $\circ / Y Y V^{* *}$ & $\varphi V / I^{* *}$ & $11 / 11^{* *}$ & $r \wedge \circ \varphi^{*}$ & $10 / 0^{\mathrm{ns}}$ & $10 \circ 0^{* *}$ & V & تيمار \\
\hline.$/ 9 \vee 0$ & $1 / 0 V$ & $0 / 009$ & $0 / 1 V$ & $1 / \wedge 9$ & $1 \circ \Delta F$ & $4 / 19$ & 109 & 19 & خطا \\
\hline$\varphi / \mu \wedge$ & $9 / \circ 0$ & $\Lambda / 01$ & $\Delta / \Delta Y^{\circ}$ & $14 / 90$ & $11 / \mathrm{V}$ & $\Delta / \Delta Q$ & $19 / 44$ & ات (.) & ضريب تغيي \\
\hline
\end{tabular}

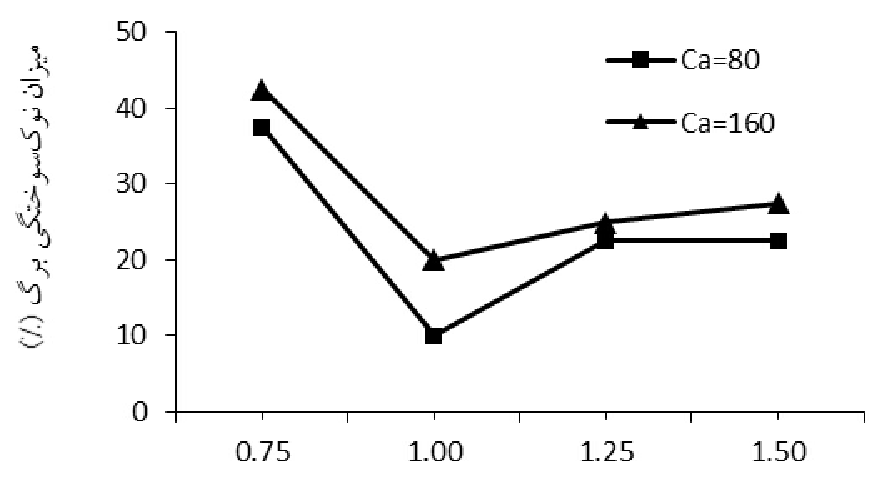

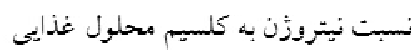

شكل ا. اثر نسبتهاى مختلف نيتروزن به كلسيم (N:Ca) در غلظتهاى مختلف كلسيم بر درصد بوتههاى دجار نوكسوختخى برى

كه مىتواند سبب افـزايش يـا كـاهش جــنب كلسـيم و شـيوع نوكسوختكى شود، ميزان نيتروزن اسـت (19). يـون نيتـرات از

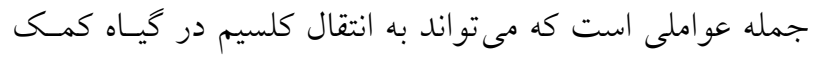

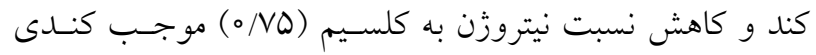
انتقال كلسيم و افزايش درصد نوك سوختخى مىشـود. بـهــور

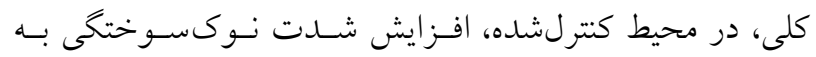
ويز گىهايى همجون دماى زياد، كه سرعت رشد كياه را تسـريع مى كند، نسبت داده مى شود (IV). سـنتز يلسى فنولازهـايى ماننـد كلروزنيك اسيد، كه يك گروه از تركيبات غيرفعال كننده آنزيمها هستند، توسط سطوح تابش زيـاد و فتويريـود طـولانى (بهـار و تابستان) تحريك مىشود. اين افزايش سطوح كلروزنيـى اسـيد در كاهو بهدليل افـزايش فعاليـت آنـزيم اينــدول اسـيكى اسـيد اكسيداز (IAA-Oxidase)، سبب افزايش توليــ اكسـين و رشــ برگ مىشود كه همين امر مانع از رسيدن سـريع كلسـيم (على
نيز كاهش يافت (1/). با توجه به غلظت بهينه كلسسيم بـرگ در همه تيمارها، بهنظر مسىرســ كـه در غلظـتهـاى بيشـتر يـون نيترات، عامل اصلى ايجاد نوكسوختكى، كاهش انتقـال كلسـيم به نوى بركهاى داخلى سر كاهو باشد، زيرا با افـزايش دمـا بـهـ بالاتر از دماى بهينه كاهو (11 درجه سلسيوس)، سـرعت رشـد كاهو افزايش مىيابد (Y) (I). اين درحالى است كه سرعت انتقـال كلسيم متناسب با سرعت رشد بركها افزايش نخواهــ يافـت و بنابر اين نوكسـوختخى افـز ايش مسى يابـــ. يكـى از راهكارهـاى

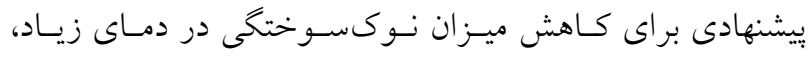
كاهش غلظت نيتروزن محلول غذايى بهمنظـور كـاهش سـرعت رشد كاهو است (سT). صرفنظر از غلظت عناصر غذايى، عواملى همجِون سـرعت

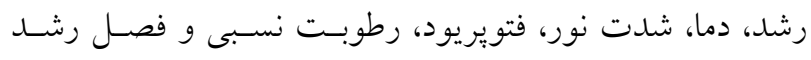

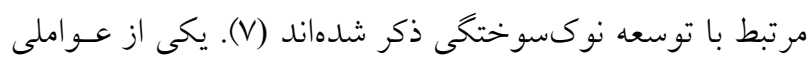




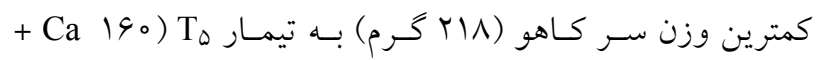

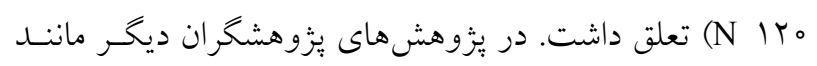

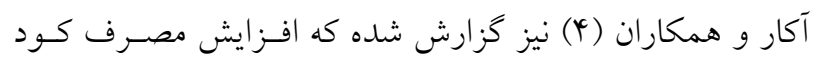
نيتروزنه از هما به همب كيلو گرم در هكتار سـبب افـزايش وزن

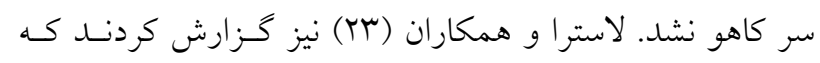

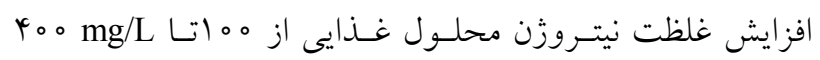
سبب كاهش وزن سر كاهو در دو رقم شد و در دو رقـم ديخــر سبب افزايش وزن سر كاهو شد. در مقابل، كـوميتى و همكـاران (19) گزارش كردند كه افزايش غلظت نيترات محلول غذايى از

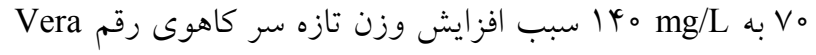
شد. در يزٔوهش آلبرسينى و همكاران (ه) گزارش شـده كـه در كشت تابستانه، كاهش غلظت محلـول غــايى تـا هr\% (كـاهش

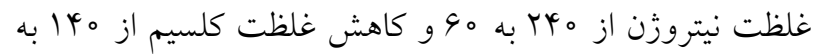
هr ميلى گرم بر ليتر) سبب كاهش وزن سـر در كـاهوى باترهـــ

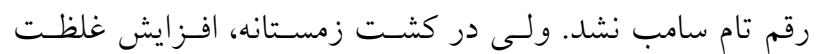
محلول غذايى سبب افزايش عملكرد شد. در غلظت م^ ميلى گرم بر ليتر كلسيم، نتايج بهتــى از نظـر عملكرد وزن سر كاهو حاصل شـد كـه ممكـن اسـت ناشسى از كاهش جذب يتاسيم در غلظت 19 mg/L كلسـيم باشـد. ايـن امر، فعاليت بسيارى از آنزيمهايى كه يتاسيم در آنهـا نقـش دارد را كاهش داده و سبب كاهش توليد يروتئين و مـواد فتوسـنتزى

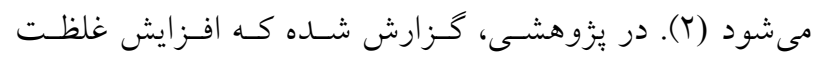

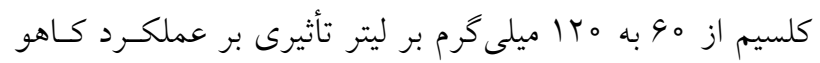

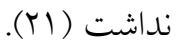

\section{وزن خشك برى}

براساس نتايج مقايسه ميـانكين (جـدول \&)، وزن خشـك انـدام

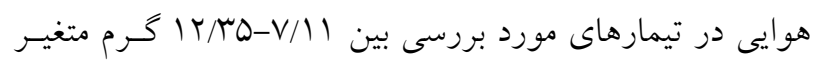

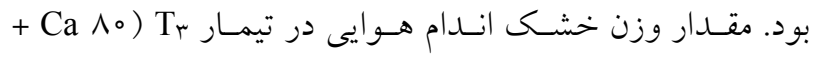

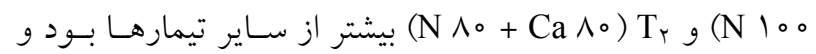

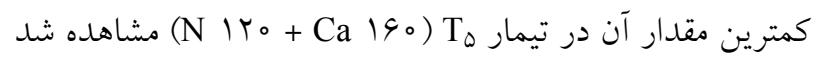

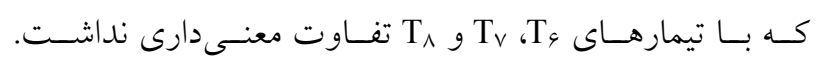

رغم وجود كلسـيم در محسيط ريشـهة) بـهـ نـوك بـرى و شـيوع نوكسوختكى مىشود. بههمين دليل بهنظر مىرسد كه ارتبـاطى

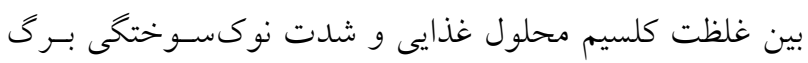

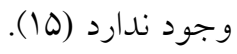

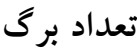

با توجه به نتايج تجزيه واريـانس دادههـا (جــول r)، تيمارهـاى مختلف اثر معنىدارى بر تعداد برگ خوراكى نداشتند. تعداد برى

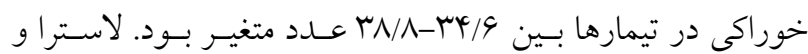
همكاران (سץ) گزارش كردند كه تعداد كـل بـرى و تعـداد بـرى خوراكى در كاهو وابسته به رقم بوده و با ميـزان نيتـروزن موجـود در محلول غذايى همبستكى ندارد. در غلظتهاى كـم نيتـروزن و كلسيم محلول غذايى، اين عناصر به سمت مريستمهـاى در حسال تقسيم سلولى حركت كرده و نياز گياه به تقسـيم سـلولى و توليــ برى را برطرف كرده و در غلظتهاى بيشـتر مسىتوانـــ موجـب كسترش سطح برى شوند (צ). فريزا و همكاران (Iا) نيز گزارش

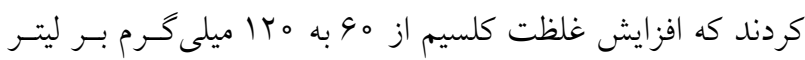
تأثيرى بر تعداد بركهاى كاهو در كشت شناورى نداشـت. نتـايج

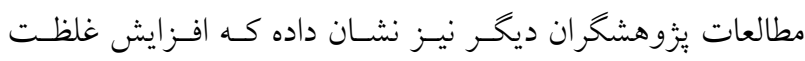

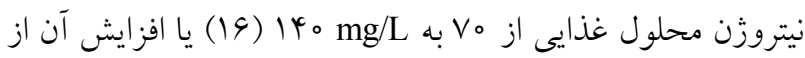

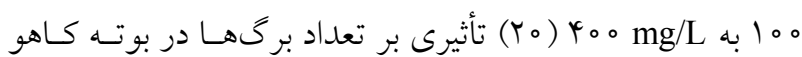
نداشت. در يزوهشى، بيان شـده كـهـ تعـداد بـركهــــ كـاهو در

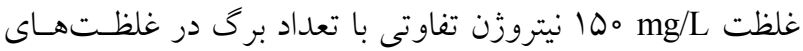

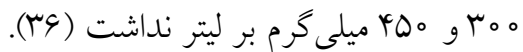

وزن سر كاهو

نتايج تجزيه واريانس دادهها (جدول س) بيانگر تـأثير تيمارهـاى مختلف بر وزن تازه بـرى در سـطح احتمـال هـ بـود. مقايسـه

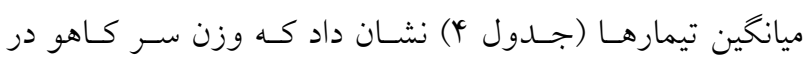

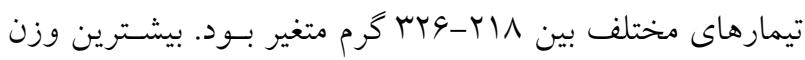

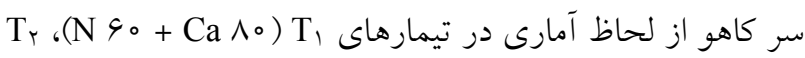
(N $100+\mathrm{Ca} \Lambda 0) \mathrm{T}_{\mathrm{Y}}$ (N $\left.\Lambda_{0}+\mathrm{Ca} \Lambda^{\circ}\right)$ 


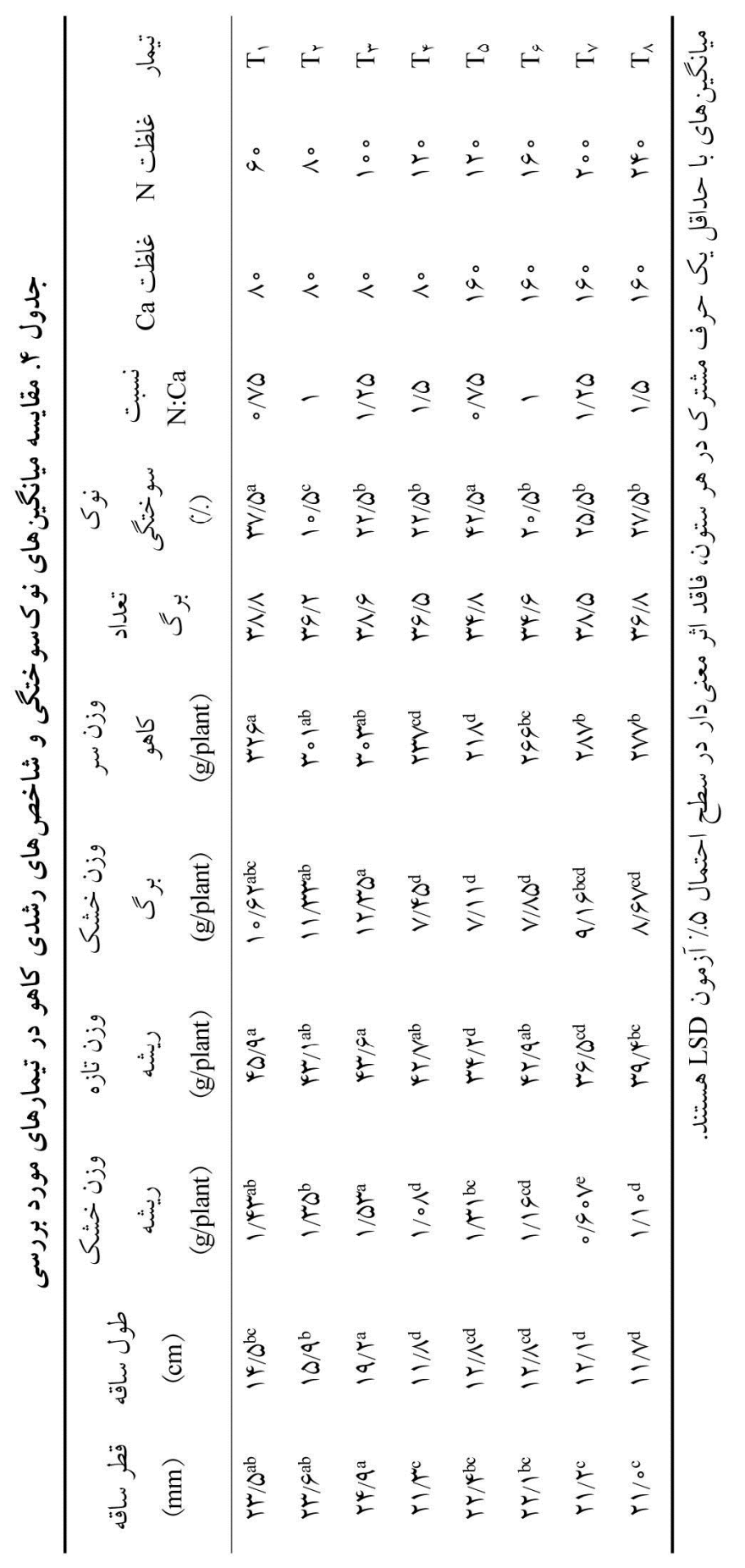


غلظتهاى كم نيتروزن، مواد فتوسنتزى بيشترى بهسمت ريشـه

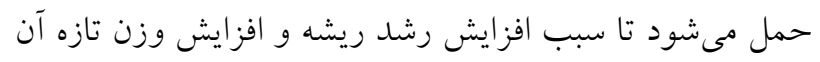

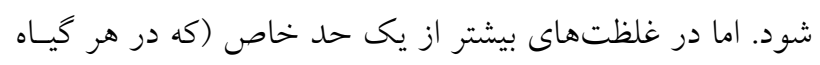

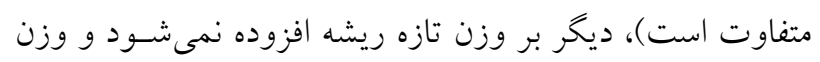

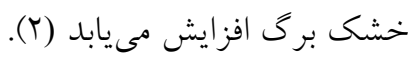
وزن تازه ريشه در غلظت هم ميلى گرم بر ليتر كلسيم بيشينه

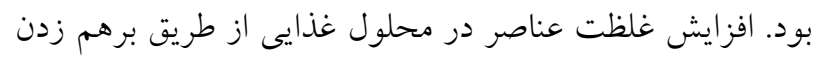

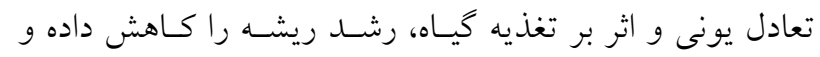

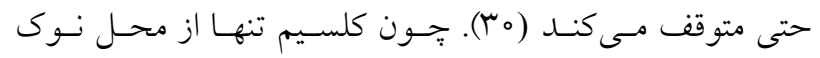

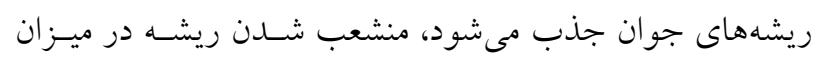

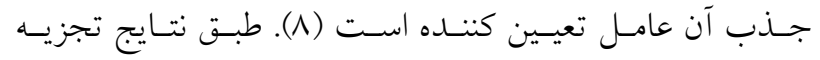

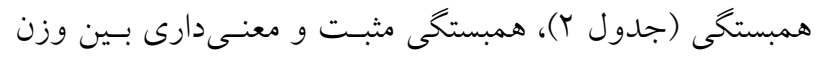
تازه ريشه و وزن تازه برى (r=/9Nk) وجود داشت. وزن تـازه

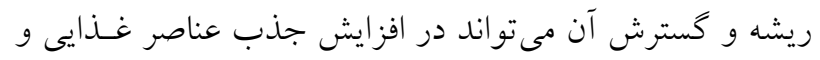

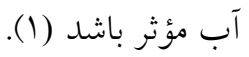

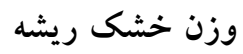

نتسايج تجزيـه واريـانس (جسـدول r) تــأثير معنسى دارى را از

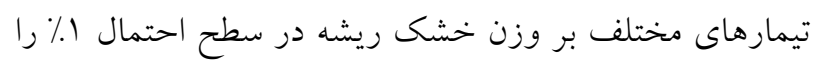

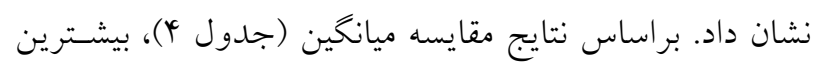

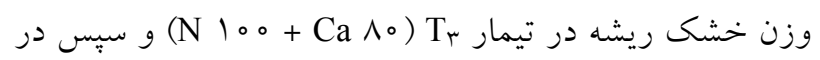

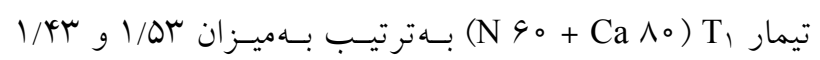

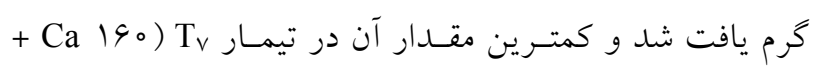

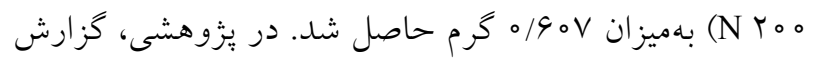

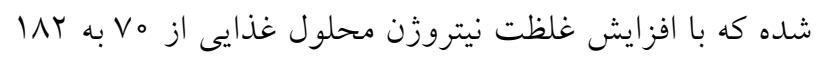

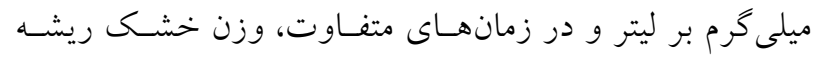

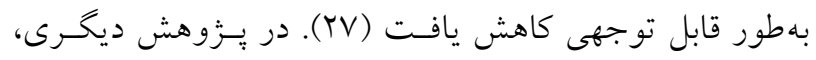

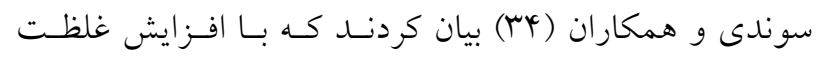

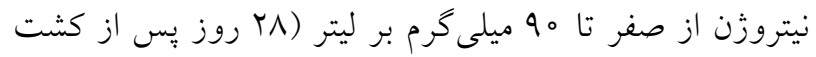

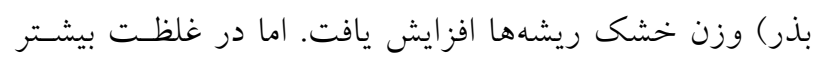

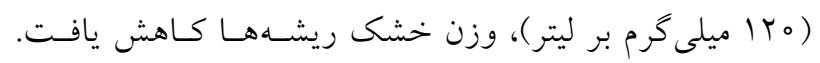

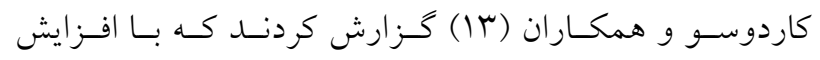

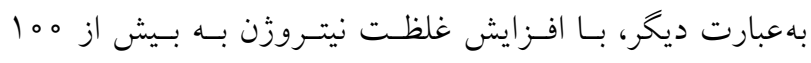

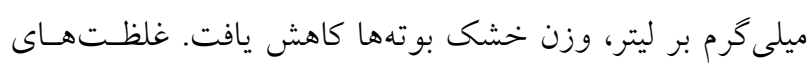

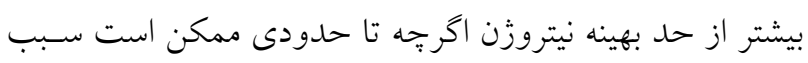

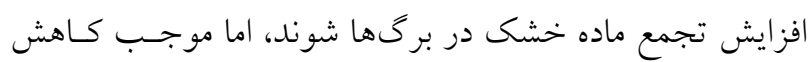

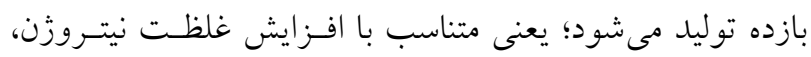

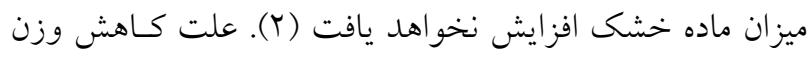
ماده خشك برى با افزايش غلظت نيتروزن، جـايخز ينى نيتـرات

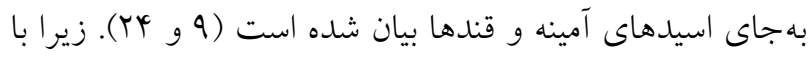

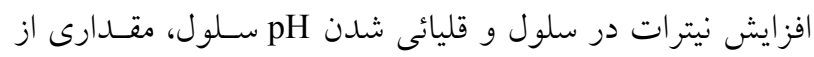

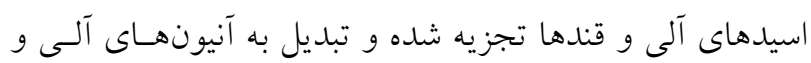

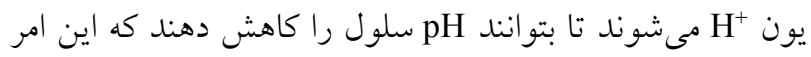
موجب كاهش وزن خشك اندام هو ايى مىشود (Y)). در غلظت

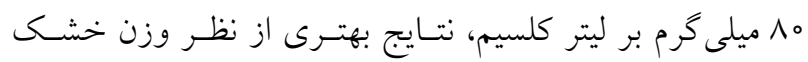

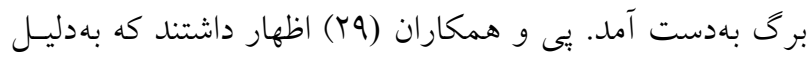

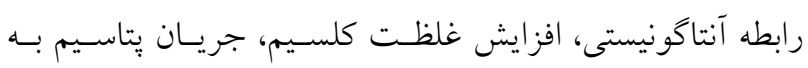

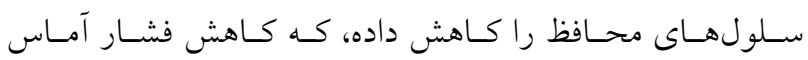

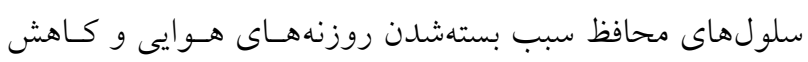

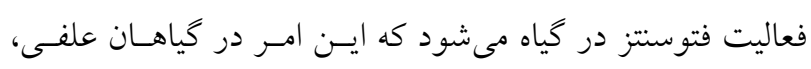

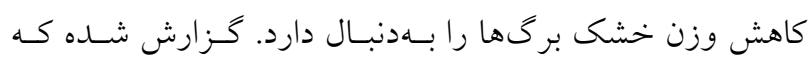

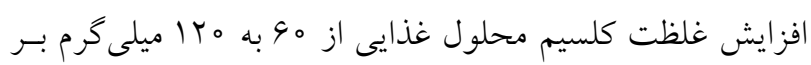

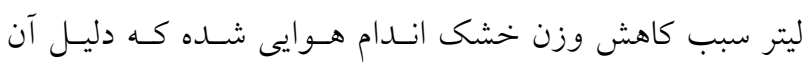
كاهش جذب يُّاسيم و منيزيم با افزايش غلظت كلسـيم محلـول

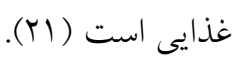

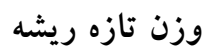

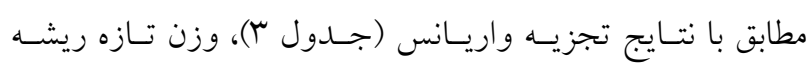

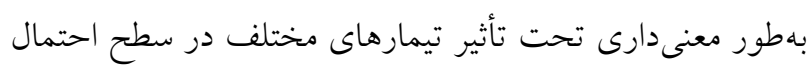

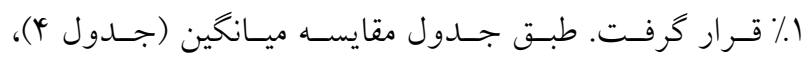

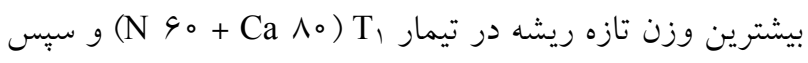

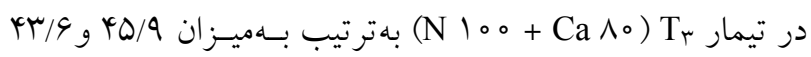

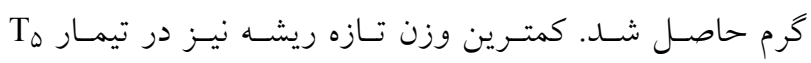
(N Iro + Ca 190) 
جدول ه. مقايسه ميانگينهاى غلظت عناصر برى (.٪) در تيمارهاى مختلف و مقايسه با غلظت بهينه

\begin{tabular}{|c|c|c|c|c|c|c|c|}
\hline $\mathrm{P}$ & $\mathrm{Ca}$ & $\mathrm{K}$ & $\mathrm{N}$ & نسبت N:Ca & غلظت Ca & غلظت N & تيمار \\
\hline $0 / \pi 90$ & $r /\left.0\right|^{c}$ & $T / Y \wedge$ & $r / Y_{\circ} b$ & $\circ / V \Delta$ & $\Lambda_{0}$ & 90 & $\mathrm{~T}_{1}$ \\
\hline $0 / 190$ & $r / \circ Y^{c}$ & T/M & $r / Y \circ b$ & 1 & $\Lambda^{\circ}$ & $\Lambda_{0}$ & $\mathrm{~T}_{\mathrm{r}}$ \\
\hline $0 / 499$ & $r / / r^{\mathrm{ab}}$ & $T / N Y$ & $r / \Delta r^{\mathrm{ab}}$ & $1 / T \Delta$ & $\Lambda \circ$ & 100 & $\mathrm{~T}_{r}$ \\
\hline orgat & $r / I V^{a}$ & $T / M V$ & $r / \Delta Y^{\mathrm{ab}}$ & $1 / 0$ & $\Lambda_{0}$ & Iro & $\mathrm{T}_{4}$ \\
\hline$\circ / \mu V 0$ & $r / \circ \varphi^{b c}$ & $T / Y \Lambda$ & $T / \& q a b$ & $\circ / V Q$ & 190 & ko & $\mathrm{T}_{\Delta}$ \\
\hline$\circ / r \vee q$ & $r / \circ q^{a b c}$ & $T / T V$ & $r / \Delta \Delta^{a}$ & 1 & 190 & 190 & $\mathrm{~T}_{4}$ \\
\hline $0 / 494$ & $r / \Lambda \Lambda^{\mathrm{a}}$ & $T / Y V$ & $r / 4 q a b$ & $1 / T Q$ & 190 & Y०० & $\mathrm{T}_{\mathrm{V}}$ \\
\hline $0 / M 4 \Lambda$ & $r / 1 \varphi^{a}$ & $T / Y Y$ & $r / \Delta r^{a b}$ & $1 / 0$ & 190 & TYO & $\mathrm{T}_{\wedge}$ \\
\hline$\circ / T \Delta-\circ / \Delta$ & $r-Y / \Lambda$ & $r / \Delta-Q$ & $r-r$ & & \multicolumn{3}{|c|}{ دامنه غلظت بهينه (Huchmuth et al, 2004) } \\
\hline $\mathrm{ns}$ & $*$ & $\mathrm{~ns}$ & $*$ & & \multicolumn{3}{|c|}{ سطح معنى دارى } \\
\hline$r / Y V$ & Y/VI & $r / 94$ & r/r & & \multicolumn{3}{|c|}{ ضريب تغييرات (\%) } \\
\hline
\end{tabular}

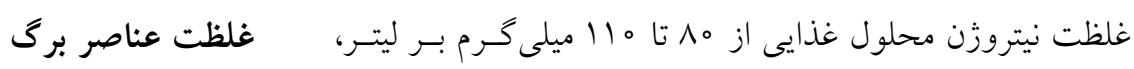

نتايج تجزيه واريانس نشان داد كه بين تيمارها تفاوت معنسى برارى از نظر غلظت نيتروزن و كلسيم برى وجود داشت؛ اما تأثيرى بـر

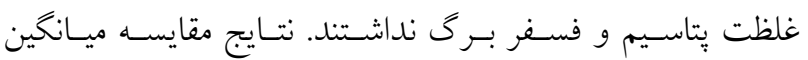

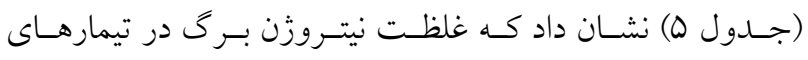

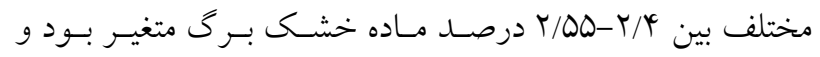
كمترين آن نيز مربوط به تيمار , با غلظت ه9 ميلى گرم بـر ليتـر

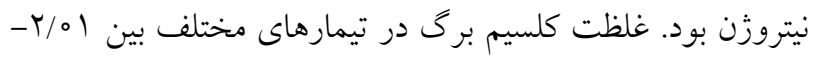

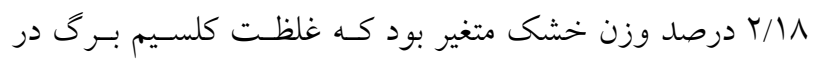

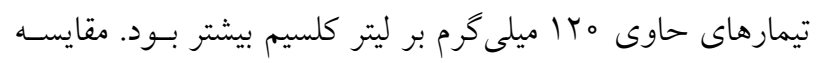

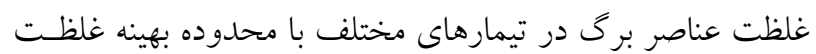

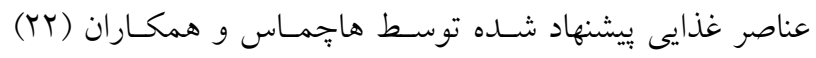

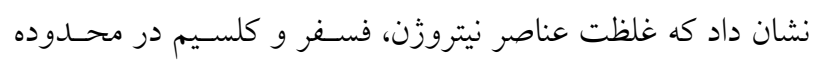

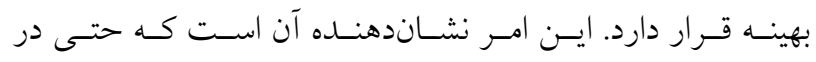

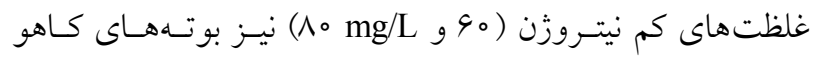

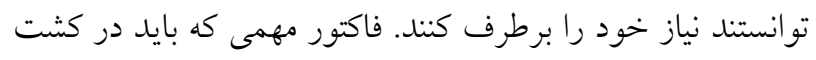

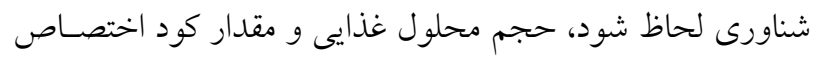

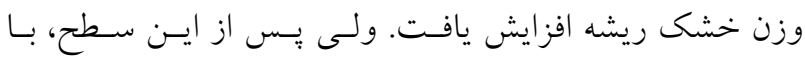

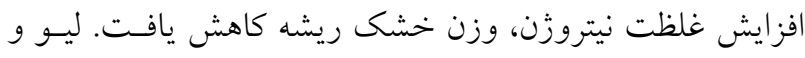

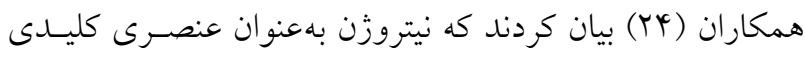
در تنظيم رشد ريشه و اندام هـوايى كـاهو محسـوب مسىشـود.

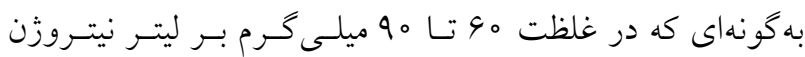
بيشترين رشد ريشه حاصل شد كه منجر به افزايش زنــدمـانى

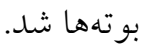

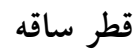
مطابق نتايج تجزيه واريانس، اثر تيمارهاى مختلف بـر صـفت قطر

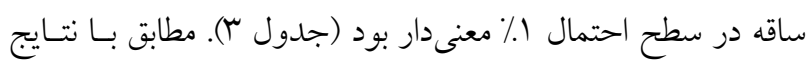

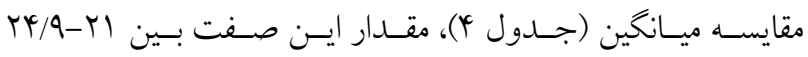

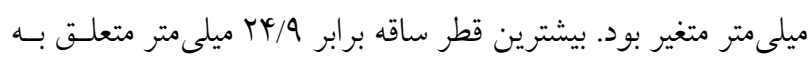

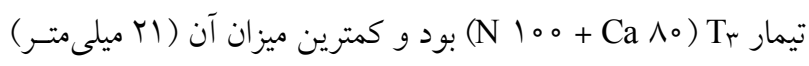

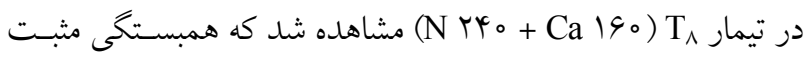
و خوبى بين قطر ساقه و وزن سر كاهو وجود دارد (1). 
خوراكى معنى دار نبود. بيشـترين وزن سـر كـاهو، طـول و قطر

Tـاقه و وزن خشـك ريشـهـ و انــام هــوايى در تيمارهــاى

$\left.+\mathrm{Ca} \wedge^{\circ}\right) \mathrm{T}_{\Gamma},\left(\mathrm{N} \wedge^{\circ}+\mathrm{Ca} \wedge^{\circ}\right) \mathrm{T}_{\Upsilon}\left(\mathrm{N} \quad \varphi_{0}+\mathrm{Ca} \wedge_{0}\right)$

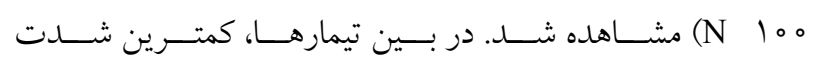

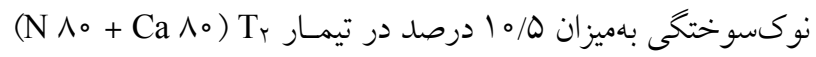

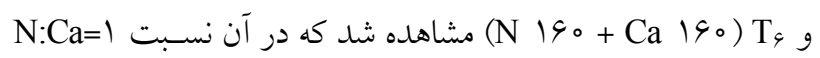

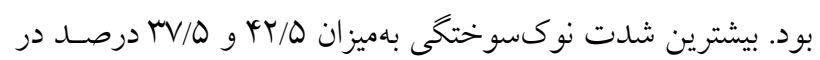

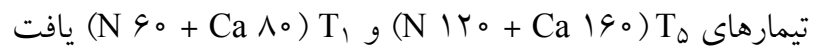

شد كه در آنها نسبت N:Ca =0/NQ. بود. بـر اسـاس نتـايج ايسن

يزوهش، در شـرايط كــرم كلخانـه (دمـاى شـبانه ما و روز ها

درجه سلسيوس)، استفاده از محلول غذايى بهميزان •م ميلى گرم

بر ليتر نيتروزن و 0م ميلى گرم بر ليتر كلسيم با توليد عملكـرد و

شاخصهاى رويشى مطلوب و ايجاد نوكسوختكى برى كمتسر

براى كشت شناورى كاهو توصيه مىشود.
يافته براى هر بوته است. در اين يزوهش، حجــم محلـول غــذايى براى هر بوته برابـر ه ليتـر بـود و بنـابراين مقـدار كـود نيتــروزن

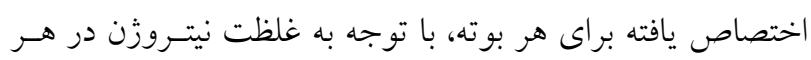

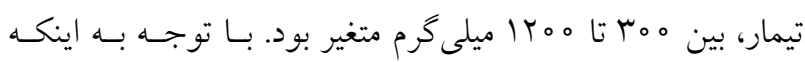
محلول غذايى يكبـار در طـول دوره تعـويض شـد، بنـابراين در

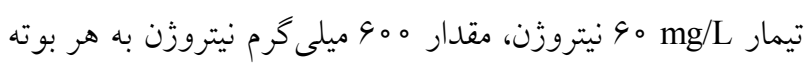
كاهو اختصاص يافت كه مقدار ه هو ميلى گرم مىتواند نيـاز يـى بوته هم گرمى كاهو به نيتروزن (با س/٪ نيتروزن در ماده خشعى) را بهراحتى تأمين كند. بنابراين، در كشتهاى شناورى، عـالوهبـر غلظت محلول غذايى، حجــم محلـول غـذايى و مقـدار نيتـروزن اختصاص يافته به هر بوته نيز حتماً بايد مدنظر قرار كيرد. نتيجه كيرى نتايج نشان داد كه اثر تيمارهاى مـورد بررسسى بـر تعـداد بـرى

\section{منابع مورد استفاده}

ا. برزكر، ر.، س. ريزى و م. خسروى. هوسا. اثر دور تعويض محلول غذايى و غلظتهاى مختلف محلول يركننده بر رشد كاهو

(Lactuca sativa L.)

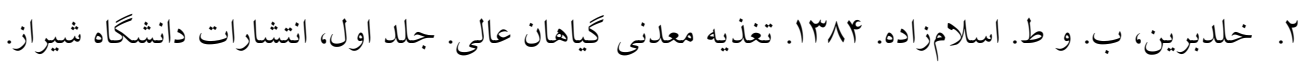

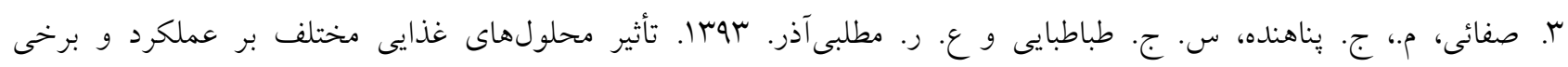

شاخص هاى رشدى كاهو در سيستم هيدرويونيك. علوم و فنون كشتهاى كلخانهاى 11:

4. Acar, B., M. Paksoy, O. Turkmen and M. Seymen. 2008. Irrigation and nitrogen level affect lettuce yield in greenhouse condition. Afr. J. Biotechnol. 7(24): 4450-4453.

5. Alberici, A., E. Quattrini, M. Penati, L. Martinetti, P. Marino Gallina and A. Ferrante. 2008. Effect of the reduction of nutrient solution concentration on leafy vegetables quality grown in floating system. Acta Hort. 801: 1167-1176.

6. Arreola, J.A., M. Ana, C. Gonzalez and E.A. Garcia. 2008. Effect of calcium, boron and molybdenum on plant growth and bract pigmentation in poinsettia. Rev. Fitotec. Mex. 31(2): 165-172.

7. Assimakopoulou, A., A. Kotsiras and K. Nifakos. 2013. Incidence of lettuce tipburn as related to hydroponic system and cultivar. J. Plant Nutr. 36: 1383-1400.

8. Barker, A.V. and D.J. Pilbeam. 2007. Handbook of Plant Nutrition. CRC Press, New York, 613 p.

9. Behr, U. and H.J. Wiebe. 1992. Relation between photosynthesis and nitrate content of lettuce cultivars. Sci. Hort. 49(3-4): 175-179.

10. Bleyaert, P., K. Vermeulen, K. Steppe and J. Dekock. 2012. Evaluation of a sensor for online measurements of stem diameter variations of leafy vegetables. Acta Hort. 927: 571-579.

11. Boroujerdnia, M. and N. Alemzadeh Ansari. 2007. Effect of different levels of nitrogen fertilizer and cultivars on growth, yield and yield components of romaine lettuce (Lactuca sativa L.). Middle Eastern and Russian J. Plant Sci. and Biotechnol. 1(2): 47-53.

12. Both, A.J. 2003. Ten years of hydroponic lettuce research. Department of Plant Biology and Pathology Rutgers, The State University of New Jersey. Available online at: http://www.ecaantu.edu.tw /weifang/ lab551/vegetable//culturapractice/ten\%20yearsof\%20hydtopon\%20lettuce\% 20 research. Pdf. Accessed 18 October 2014. 
13. Cardoso, F.L., J.L. Andriolo, M. Dal Picio, M. Piccin and J.M. Souza. 2015. Nitrogen on growth and yield of lettuce plants grown under root confinement. Hort. Bras. 33: 422-427.

14. Cocetta, G., E. Quattrini, M. Schiavi, L. Martinetti, A. Spinardi and A. Ferrant. 2007. Nitrate and sucrose content in fresh-cut leaves of spinach plants grown in floating systems. Agr. Med. 137: 1-7.

15. Collier, G.F. and T.W. Tibbitts. 1980. Tipburn of lettuce. Hort. Rev. 4: 49-65.

16. Cometti, N.N., M.Q. Martins, C.A. Bremenkamp and J.A. Nunes. 2011. Nitrate concentration in lettuce leaves depending on photosynthetic photon flux and nitrate concentration in the nutrient solution. Hort. Bras. 29: 548-553.

17. Corriveau, J., L. Gaudreau, J. Caron, S. Jenni and A. Gosselin. 2012. Effect of water management, fogging and Ca foliar application on tipburn of romain lettuce (Lactuca sativa L.) cultivated in greenhouse. Acta Hort. 927: 475480.

18. Das, B.K. and S.P. Sen. 1981. Effect of nitrogen, phosphorus and potassium deficiency on the uptake and mobilization of ions in Bengal gram (Cicer arietinum). J. BioSci. 3(3): 249-257.

19. Dzida, K., Z. Jarosz, Z. Michalojc and R. Nurzynska-Wierdak. 2012. The influence of diversified nitrogen and liming fertilization on the chemical composition of lettuce. Acta Sci. Pol., Hortorum Cultus. 11(3): $247-254$.

20.FAO. 2012. Lettuce and chicory production quantity. Available online at http://faosta3.fao.org/ home/ index.html $\neq$ download .Accessed 2 October 2016.

21. Frezza, D., A. Leon, V. Logegaray, A. Chiesa, M. Desimone and L. Diaz. 2005. Soilless culture technology for high quality lettuce. Acta Hort. 697: 43-48.

22. Hochmuth, G., D. Maynard, C. Vavrina, E. Hanlon and E. Simonne. 2004. Plant tissue analysis and interpretation for vegetable crop in Florida. University of Florida Special Publication SS-VEC- 42.

23. Lastra, O., M.L. Tapia, B. Razeto and M. Rojas. 2009. Response of hydroponic lettuce cultivars to different treatments of nitrogen: Growth and foliar nitrate content. IDESIA (Chile) Enero. 27(1): 83-89.

24. Liu, C., Y. Sung, B. Chen and H. Lai. 2014. Effects of nitrogen fertilizers on the growth and nitrate content of lettuce (Lactuca sativa L.). Int. J. Environ. Res. Public Health 11(4): 4427-4440.

25. Mardani Nejad, S.H., B. Kholdbarin, Y. Saadat, A. Moradshahi and M. Vazirpour. 2003. Effect of nitrogen on growth behavior and essential oil of Lavandula officinalis L. Iran. J. Med. Arom. Plants Res. 19: 16-35.

26. Marschner, H. 2012. Mineral Nutrition of Higher Plants. Academic Press, London.

27. Marsic, N.K. and J. Osvald. 2002. Effects of different nitrogen levels on lettuce growth and nitrate accumulation in iceberg lettuce (Lactuca sativa L. var. Capitata) grown hydroponically under greenhouse conditions. Gartenbauwissenschaft 67(4): 128-134.

28. Nemadodzi, L.E. 2015. Growth and development of baby spinach (Spinacia oleracea L.) with reference to mineral nutrition. MSc. Dissertation, University of South Africa, Pretoria.

29. Pei, Z.M., Y.G. Murata, S. Benning, B. Thomine, G. Klusener, J. Allen, E. Grill and J.I. Schroeder. 2000. Calcium channels activated by hydrogen peroxide mediate abscisic acid signaling in guard cells. Nature 406: 731-734.

30. Phommy, I., N. Yasuyo and F. Yasufumi. 2012. Effect of potassium sources and rates on plant growth, mineral absorption, and the incidence of tipburn in cabbage, celery, and lettuce. Hort. Environ. Biotechnol. 53(2): $135-142$.

31. Samarakoon, U.C., P.A. Weerasighe and A.P. Weerakodi. 2006. Effect of electrical conductivity (EC) of the nutrient solution on nutrient uptake growth and yield of leafy lettuce in stationary culture. Trop. Agric. Res. 18: 1321.

32. Santamaria, P., A. Elia and F. Serio. 2002. Effect of solution nitrogen concentration on yield, leaf element content, and water and nitrogen use efficiency of three hydroponically-grown rocket salad genotypes, J. Plant Nutr. 25(2): $245-258$.

33. Smith, R., T. Hartz and R. Hayes. 2011. Overview of tipburn of lettuce. Salinas valley agriculture, highlighting agricultural developments, problems, research, AND issues for central coast CA. Available online at: http://ucanr.edu/blogs/blogcore/postdetail.cfm? postnum=5608.

34. Sounday, P. and D.J. Cantliffe. 2001. Improving lettuce transplant quality in response to nitrogen nutrition in a floatation production system. Proc. of the Florida State Hort. Soc. 114: 294-303.

35. Trejo-Tellez L.I. and F.C. Gomez-Merino. 2012. Hydroponics-A standard methodology for plant biological researches. Available online at: http://www.intechopen.com, pp. 1-23.

36. Tsiakaras, G., S.A. Petropoulos and E.M. Khah. 2014. Effect of GA and nitrogen on yield and marketability of lettuce (Lactuca sativa L.). Aust. J. Crop Sci. 8(1): 127-132.

37. Zamaniyan, M., J. Panahandeh, S.J. Tabatabaei and A. Motallebie-Azar. 2012. Effects of different ratios of K:Ca in nutrient solution on growth, yield and chicon quality of witloof chicory (Cichorium intybus L.). Int. J. AgriSci. 2(12): $1137-1142$. 


\title{
Effect of Nitrogen and Ccalcium Concentration in Nutrient Solution on Growth, Yield and Tipburn of Butterhead Lettuce in Floating System
}

\author{
E. Mortezavi ${ }^{1}$, R. Barzegar ${ }^{1^{*}}$ and S. Reezi ${ }^{1}$
}

(Received: 7 February 2017 ; Accepted: 18 August 2017)

\begin{abstract}
The present investigation was carried out to evaluate the impacts of different concentrations of $\mathrm{N}$ and $\mathrm{Ca}$ and $\mathrm{N}$ :Ca ratio in nutrient solution on growth indices, yield and tipburn of butterhead lettuce (Lactuca sativa var. Capitata) in floating system. The experiment was conducted as completely randomized design, with 8 treatments and 3 replications, in Research Greenhouse of Shahrekord University. Treatments (different concentrations of Ca and N (mg/L) in the nutrient solution) included $\mathrm{T}_{1}(\mathrm{~N} 60+\mathrm{Ca} 80), \mathrm{T}_{2}(\mathrm{~N} 80+\mathrm{Ca} 80), \mathrm{T}_{3}(\mathrm{~N} 100+\mathrm{Ca} 80), \mathrm{T}_{4}(\mathrm{~N} 120+\mathrm{Ca} 80), \mathrm{T}_{5}(\mathrm{~N} 120+$ $\mathrm{Ca} 160), \mathrm{T}_{6}(\mathrm{~N} 160+\mathrm{Ca} 160), \mathrm{T}_{7}(\mathrm{~N} 200+\mathrm{Ca} 160)$ and $\mathrm{T}_{8}(\mathrm{~N} 240+\mathrm{Ca} 160)$. Results showed that there was no significant difference between treatments for number of leaves; but significant differences were observed in tipburn percent, leaf and root fresh weight, leaf and root dry weight, and stem length and diameter. The highest head weight, length and diameter of stem, and root and leaf dry weight were observed in $\mathrm{T}_{1}(\mathrm{~N} 60+\mathrm{Ca} 80), \mathrm{T}_{2}(\mathrm{~N} 80+\mathrm{Ca} 80)$ and $\mathrm{T}_{3}(\mathrm{~N} 100+$ $\mathrm{Ca} 80$ ) treatments. The weight of head in different treatments varied from 218 to $326 \mathrm{~g} / \mathrm{plant}$. Increasing the $\mathrm{N}$ concentration to more than $100 \mathrm{mg} / \mathrm{L}$ decreased the yield. Higher yield was obtained in $80 \mathrm{mg} / \mathrm{L} \mathrm{Ca}$ concentration as compared to $160 \mathrm{mg} / \mathrm{L}$. The tipburn occurrence of the treatments varied from 10.5 to 42.5 percent. The lowest tipburn occurrence was observed in $\mathrm{T} 2$ and $\mathrm{T} 6(\mathrm{~N}: \mathrm{Ca}=1)$ treatments; while it was highest in $\mathrm{T} 1$ and $\mathrm{T} 5(\mathrm{~N}: \mathrm{Ca}=0.75)$ treatments. Leaf analysis showed that significant difference was observed among the treatments with respect to $\mathrm{N}$ and $\mathrm{Ca}$ content. The $\mathrm{T} 2$ treatment $(\mathrm{N} 80+\mathrm{Ca} 80)$ was the best due to its high yield and lower tipburn incidence.
\end{abstract}

Keywords: Lettuce, Soilless culture, Nutrients ratio, Head weight, Leaf nitrogen.

1. Dept.of Hort. Sci., College of Agric., Shahrekord Univ., Shahrekord, Iran.

* Corresponding Author, Email: Barzegar56@yahoo.com 